\title{
The Influence of Engagement as A Mediator among Leadership and Turnover Intention on Workers in Lembaga Pendidikan Indonesia Amerika
}

\author{
Tony Hartono \\ Department of Management \\ Faculty of Economics and Business, Universitas Indonesia \\ Depok, Indonesia hartono21.tony@gmail.com
}

\begin{abstract}
-
The researcher organized this research on seventy nine permanent staffs from all branch offices of Lembaga Pendidikan Indonesia Amerika (LPIA) where spread across at all Java Island (including DKI Jakarta). This research objective was to investigation the influence of work engagement as a mediator on transformational leadership to turnover intention. The outcomes indication that work engagement has an influence as a full mediator among transformational leadership on turnover intention. This concluded that transformational leadership must go through work engagement before it can affect turnover intention. Practicing good transformational leadership attitudes might improve work engagement and could thus reduce turnover intention.
\end{abstract}

Keywords-Turnover intention, work engagement, transformational leadership

\section{INTRODUCTION}

In Indonesia, we recognize two types of education: formal and informal. Formal education occurs in schools and colleges, whereas informal education occurs in course-giving institutions. According to Article 13 paragraph 1 of Act number 20 of 2003, education organized by the course-giving institution can contribute education to the nation as a form of informal education. There are is lot of informal education in Indonesia. Based on the data that the authors obtained from Direktorat Jenderal Pendidikan Anak Usia Dini dan Pendidikan Masyarakat Kementerian Pendidikan dan Kebudayaan in 2017, there were 76 types of informal courses organized by 29,283 institutions.

Interestingly, a research reported in the EF English Proficiency Index found that, in 2015, the English proficiency of Indonesians was ranked $32^{\text {nd }}$ out of 70 countries [1]. According to the Direktorat Jenderal Pendidikan Anak Usia Dini dan Pendidikan Masyarakat Kementerian Pendidikan dan Kebudayaan of the Republic of Indonesia, Muhyiddin [1] said that communicative abilities became very important during this era of ASEAN economic community and the improvement of English competence needed to be done continuously side by side with the implementation of formal education [1]. CEO Karir.com, Martin [1] said that in ASIA the level of English proficiency among Indonesians was still below Malaysia and India, followed by South Korea, Vietnam, Japan, and Taiwan [1]. This level showed that there is a need for awareness among Indonesians to improve their English language skills with support from various education sectors [1]. Williams, et al [2] said that English had an influence on the labor market.

\author{
Yanki Hartijasti \\ Department of Management \\ Faculty of Economics and Business, Universitas Indonesia \\ Depok, Indonesia yankihartijasti@yahoo.com
}

Given the fact that the ranking of English proficiency of Indonesians was still at 32 out of 70 countries, and that Indonesia was still inferior to some countries in ASIA, the authors argue that the role of informal institutions is very important in helping Indonesians become more proficient in English. At the time of the research, there were a lot of informal institutions providing English language learning services in Indonesia including English First, International Language Program, Oxford, The British Institute, SPEC, LIA, Primagama, English, Wall Street, and LPIA.

The number of English learning institutions has made the competition quite tight among existing institutions. Mr. Anton as LPIA's marketing director [3] explained that the institutions providing English language teaching services were a business unit of economic activities that not only produced products in physical or constructive form, but in their activities they also had to be able to provide a different product that was perceived to be unique, enabling the institution to attract greater public interest. One example was the American-Indonesian Education Institute (LPIA).

The number of informal education institutions - as many as 29,283 - was not tracked by the availability of existing human resources for both teachers and managers [4]. Based on data and number from the Department of Education and Culture in 2015 showed that the informal education industry nationally still lacked human resources amounting to some 32,087 people [4]. By 2015, total human resources in the informal education industry nationwide amounted to only 45,175 people, while it required around 77,262. Based on those data, the researchers conducted an analysis of just how tight is competition among informal education institutions and just how well the strategy that they have undertaken to beat the competition has been working. Yet, the common perception is that the problem of human resources in the industry of informal education has yet to be fixed.

When the national informal education industry was short of human resources, researchers found the fact LPIA actually experienced problems with respect to those resources. Indeed, the decreasing number of human resources available from 2011 to 2016 (Table 1) and the level human resource turnover in LPIA was very high [5]. The researcher analyzed that if the LPIA were able to find solutions to human resource problems that existed when national competitors in the informal education industry lacked human resources, LPIA would have beat the competition.

Without human resources companies would not function [6]. Much effort has been expended by companies to make 
workers feel comfortable and engaged in their jobs so that the company can maintain them as assets. By forging engaged workers means that workers will provide their best for the company [7]. Saks [8] argued that when workers were engaged in a job they tended to have a $(+)$ connection with their employer, they would work as well as possible for the company, and therefore would have the intention to stick with it.

The methods firms used to engage them included giving them a chance to be good leadership models [7]. Gyensare, Tsede, Sanda, and Okpoti [9] explained that transformational leadership was so defined to inspire and motivate followers to achieve outcomes further than expectations and assistance followers to raise and grow by responding to their individual requirements. There were some companies that have already felt the $(+)$ influences of retaining their workers in terms of workers. He expressed during his time serving as a Branch manager at Depok 2 that the initiative of LPIA personnel was very low. LPIA thus needed leader who was able to lead and guide them so they could work better and be tied to their jobs. The same complaint about LPIA leadership emerged among representatives of the Kampung Artis branch, where LPIA still lacked leaders with a good attitude [13]. According to Kurniawan [14] as representative of the Buaran branch, said that his staffs in his branch missed a leader who can motivate them to work contentedly and to exert their time and energy for the sake of LPIA.

The necessity for a leader who can take care of the needs of his workers, can guide them, and can provide them motivation is included in the characteristics of transformational leadership. Gyensare, et al. [9] explained that in transformational leadership could motivate his

TABLE I. AVERAGE NUMBER OF PERMANENT WORKERS IN EACH BRANCH OFFICE OF LPIA

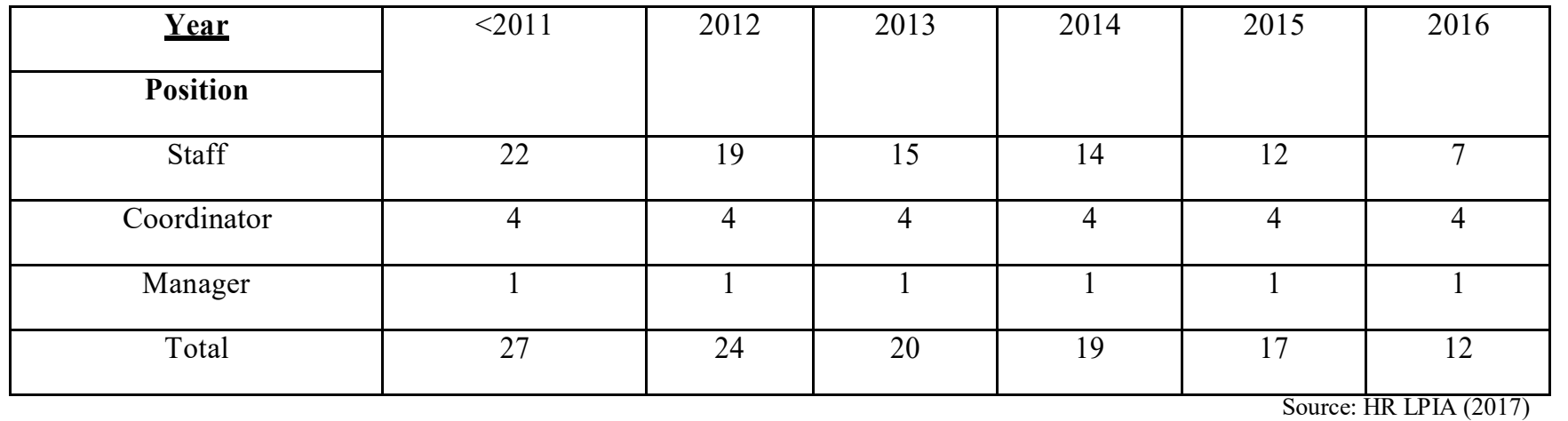

their competitive advantage [9], but unfortunately there were companies that still have not considered the importance of the concept. Many workers have resigned from the company because they had problems with their superiors [9].

Moreover, the importance of having leaders who were able to help their followers to raise and grow by responding to their individual requirements to be engaged were conducted by Hayati, Charkhabi and Naami [10], considering 240 sisters in 5 public hospitals with the outcome that transformational leadership had a significant and (+) connection on work engagement. In this research, the researchers raised phenomena associated with the existing human resources in LPIA. This effort is supported by Leana and Van Buren [11] who showed that promoting stability among individuals and having the flexibility to comprehend how individuals were set in the connection, a unit could further improve its outcome. The information was based on data from the HR department of LPIA comparing the average percentage of worker turnover in LPIA branch offices annually.

Herny [5] explained that issues related to human resources in LPIA branch offices were that the workers working in LPIA branch offices lacked a sense of engagement in their work, which was predicted to trigger higher worker turnover at LPIA. Herny [5] added that leadership issues were the explanation why some workers were disappointed and decided to leave. Herny [5] further reported that the branch manager of Bintaro resigned due to feeling something was wrong with the leadership style of LPIA. He felt ignored by the leadership even though he had worked well within LPIA. Seda [12] provided information that LPIA workers needed a leader who was able to guide followers to achieve high expectations and realize the desired future state. Gyensare et al. [9] said that transformational leadership was aware of the needs of its followers. It can have an ideal influence on its followers so that it is expected to lead them to work better.

This research is expected to have advantages and benefits for workers in LPIA, its organization, and for academics:

1. LPIA workers $\rightarrow$ For workers at the LPIA, this research has the advantage of helping determine what factors can increase their outcome in employment so it can benefit them so that they augment their high vigor, determination, and absorption in their daily duties and, finally, that they will continue to work for LPIA.

2. LPIA (Organization) $\rightarrow$ Organizationally, this research provides an advantage to companies that can discover factors that can retain qualified workers so that they will continue to work for the company, such that later on the companies will garner a competitive advantage.

3. For Academics (Macro) $\rightarrow$ This research provides a $(+)$ contribution to the academic world and benefits it by forming the process of allocating HR management knowledge, especially that related to transformational leadership, work engagement, and turnover intention. In addition, this research also provides an additional research to add to the extant literature on the variables studied. 


\section{LITERATURE REVIEW AND HYPOTHESIS DEVELOPMENT}

Maintaining human resources as company capital is very important for the business. Hitt, et al. [11] defined human capital as a level of knowledge, skills, and capabilities used to produce the desired outcomes of the firm. Stable connections among humans were mentioned by Nahuiet and Ghoshal [11] as being something created by the parties in the connection. According to Leana and Van Buren [11], by prioritizing stability among individuals and thus benefiting individuals in the connection, unity improves outcome. Frank and Cook [11] stated that a unit that having a stable and related tenure and trust, produces better outcome. Increasing human resources is thus more important than outcome itself, because through human resources better outcome is maintained.

\section{A. Turnover Intention}

Carmeli and Weisberg [15] said that turnover intention was an important issue for maintaining an organization's competitiveness in terms of maintaining human resources. Tett and Meyer [16] defined turnover intention as a cognizant and planned desire to resign from organization. Carmeli and Weisberg [15] interpreted turnover intention as a tendency that allowed an individual to resign from organization immediately. A lot of causes are able to forecast turnover intention. In a research conducted by Hofhuis, Zee, and Otten [16], they said that job remunerations, work comfortable, career growth, individual operational, colleagues, supervisors, and organizational philosophy could predict turnover intention. Slatten, Svensson, and Sværi [17] surveyed one thousands seventy six frontline workers at service organization, providing the outcome that workers' perceived service quality had (-) connection with worker turnover intention. YT Wong, YW Wong, and CS Wong [18] looked at 247 workers in three different joint venture companies in the People's Republic of China, concluding that perceived organizational support and affective commitment have a significant and (-) connection on worker turnover intention.

\section{B. Transformational leadership}

In similar research, researchers chose to observe transformational rather than other types of leadership because, according to Nemanich and Keller [9], transformational leadership was a form of influenceive leadership at the organizational level. According to GarcíaMorales, et al. [9], it was likewise influenceive at the sectoral level. Howell and Avolio [9] confirmed the same at the national level. Yukl [9] said that leadership was about to handle other people like teach them the way how they have to do on their jobs, the procedure to help each other not only in groups but also personal, and persuading each other's to recognize about their requirements or needs in order to achieve common objectives. On the theory of MLQ (Multifactor leadership questionnaire) suggested that the transformational mode offered the greatest empirical construction. Howell and Avolio [9] said that transformational leadership was very important because it allowed our staffs could work together to reach the goal effectively and efficiency even though they came from varied backgrounds. Bass and Riggio [9] and Mullins [9] stated that transformational leadership emphasized changes that can encourage each other to show their best. Furthermore, according to Bass [9], transformational leadership encouraged a high level of worker adulthood and ideal worries about achievement, self-actualization, and the welfare of others. Rendering to Gumusluoglu and Ilsev [9], the leader who could give sympathetic and meaning to each others were included in the group of transformational leaders. Therefore, Bass and Riggio [9] suggested that transformational leadership aligns the purposes and aims of its followers with the organization and gives them support and guidance.

Since its introduction, transformational leadership has become, and remains, the most researched leadership theory. The most commonly accepted structure of transformational leadership, according to Gyensare, et al. [9], contains of $4 \mathrm{sub}$ dimensions: idealized influence, inspirational motivation, intellectual stimulation, and individualized consideration. Although several criticisms have been raised against the theory, researchers have still chosen to make it one independent variable for 2 explanations. First, they were seen as an influential form of leadership from the organizational levels to countrywide levels. Second, Judge and Piccolo [9] stated that the style of transformational leadership showed the uppermost whole cogency and have a better style than other styles of leadership

\section{Work Engagement}

Schaufeli and Bakker [19] defined work engagement as something $(+)$ related to work that includes three dimensions, namely vigor, dedication, and absorption. Vigor is categorized by great levels of energy and psychological endurance. Dedication refers to the involvement of someone with their work and feeling excited about it. Absorption refers to being completely concentrated and absorbed in one's work so that time passes rapidly. There were a lot of empirical literatures about work engagement has a (-) influence on turnover intention [20]; [8]; [19]; [21] nowadays. Congruently, Shuck and Wollard [21] conducted a research to examine the connection among affective commitment, job fit, and psychological climate as the work engagement's antecedents and turnover intention and discretionary effort as the work engagement's consequences. They established that work engagement had a non-significant connection on turnover intention and had a low prediction level on worker's turnover intention. Schaufeli and Bakker [19] examined a research model to define the potential antecedents and consequences of engagement in one thousands six hundred and ninety eight workers in Netherlands. The outcomes presented that work engagement had (-) connection on turnover intention.

There were a number of explanations to expect that work engagement is negatively related to turnover intention. First, based on the experience that engagement was described as satisfying positive working conditions related to the mind [19], according to Avey, Wernsing, and Luthans [22] and Sonnentag [22] engagement was positively related to health. These positive experiences and emotions function as energy resources that may outcome in workers' desire to remain within an organization. The second explanation, according to societal interchange theory per Blau [22], when conditions are adequate workers and employers obey each other, and the outcome was a connection of trust and loyalty. That statement is also supported by statements from Cropanzano and Mitchell [22]. Saks [8] argued that when workers engaged in their jobs, doing so was a form of retaliation in a profitable 
exchange within an organization. As a outcome, engaged workers tended to have a $(+)$ connection with their employers and therefore maintained their intention to remain within an organization.

\section{Influence Among Transformational Leadership and} Turnover Intention with Work Engagement as a Mediator

Past research conducted by Hoper, Muser, and Janneck [23], Ghadi, Fernando, and Caputi [24], Hayati, Charkhabi and Naami [10], Wang, C. Li and X. Li [25] presented that transformational leadership had a significant and (+) connection with work engagement. Wells and Peachey [26] confirmed that transformational leadership has a direct (-) influence on turnover intention. Similarly, Green, Miller, and Aarons [27] concluded that transformational leadership had (-) connection with turnover intention.

There were several previous studies on transformational leadership connections and work engagement done by Hoper, Muser, and Janneck [23]. Their studies presented that transformational leadership has a $(+)$ connection to work engagement. Hayati, Charkhabi, and Naami [10] found that transformational leadership had a significant and (+) connection to work engagement. Wang, C. Li, and X. Li [25] presented that transformational leadership had a significant and $(+)$ connection to work engagement. There was a previous research, too, that discussed the connection among work engagements and turnover intention. Other research by Agarwal, Datta, Beard, and Bhargava [28] showed that work engagement and turnover intention had (-) connection. Karatepe [41] concluded that work engagement negatively impacted turnover intention, too.

A research in 2016 by L. Lu, ACC Lu, Gursoy, and Neale [29] and Camgoz, Ekmekci, Karapinar, and Guler [31] had the result about a connection of (-) and significant outcomes among work engagement and turnover intention. Memon, Salleh and Baharom [30] established that work engagement had a very strong (-) connection to turnover intention. Therefore, based on facts on the ground, supported by the aforementioned previous research, the hypothesis in this research has to do with the influence of work engagement as a mediator among transformational leadership and turnover intention.

\section{RESEARCH METHOD}

Researchers used a type of descriptive research that Malhotra [32] described as aiming demonstrate function or characteristics. The supporting collection methods used took the form of questionnaires with closed questions, accompanied by multiple-choice answers, where respondents chose one answer from the available options. Malhotra [32] explained that the questionnaire is a form of structured technique to collect data and consists of a set of written questions and oral questions answered by respondents.

The population and samples that the researcher carefully examined were workers at LPIA. By using Slovin's formula related to total permanent workers in LPIA who worked in a branch office of LPIA, as many as 164 respondents, the researcher set error tolerance limit equal to $10 \%$. Hence, he obtained an amount for the minimum sample that had to be fulfilled in this research: 62 respondents. A $10 \%$ tolerance limit of error was also used in Pawirosumarto, Sarjana, and Muchtar [33] studies.

According to Cooper and Schindler [42], there were several measurement scales: nominal, ordinal, interval, and ratio. In this research researchers used questionnaires with interval scales. The scale of the interval belongs to the category of metric scale for any given object given independently within a series of stimuli [35]. In this research each respondent was asked his views on thirty-four points of statement contained in the questionnaire by using a Likert scale from one to five. Initially the researcher questionnaires were dispersed at the annual working meeting held in Solo (at the Novotel hotel in mid-March 2017), then continued by traveling around LPIA branches around Jakarta and Bekasi and met directly with their respective managers in order to meet with all existing workers and fill in on the same day. The rest the researchers sent in the questionnaire using TIKI and JNE for branches outside the area.

TABLE II. Deleted St ATEMENT Item

\begin{tabular}{|c|c|c|c|c|}
\hline Variable & Dimensions & No. & Deleted Statement Item & SFL \\
\hline \multirow[t]{2}{*}{$\begin{array}{l}\text { Transformational } \\
\text { Leadership }\end{array}$} & \multirow[t]{2}{*}{$\begin{array}{c}\text { Individual } \\
\text { Consideration }\end{array}$} & Q3 & $\begin{array}{l}\text { My boss thinks I have diverse needs, skills, and } \\
\text { objectives than others. }\end{array}$ & 0.366 \\
\hline & & Q4 & My boss assisted me to improve my strengths. & 0.463 \\
\hline \multirow[t]{5}{*}{ Work Engagement } & \multirow[t]{3}{*}{ Vigor } & Q1 & While working I feel energized and full of energy. & 0.589 \\
\hline & & Q3 & $\begin{array}{l}\text { When I wake up in the morning, I immediately think } \\
\text { about my work. }\end{array}$ & 0.620 \\
\hline & & Q2 & When I work, I forget everything around me. & 0.611 \\
\hline & \multirow[t]{2}{*}{ Absorption } & Q4 & I am dissolved by my work. & 0.586 \\
\hline & & Q6 & It is hard to escape from my job. & 0.665 \\
\hline
\end{tabular}




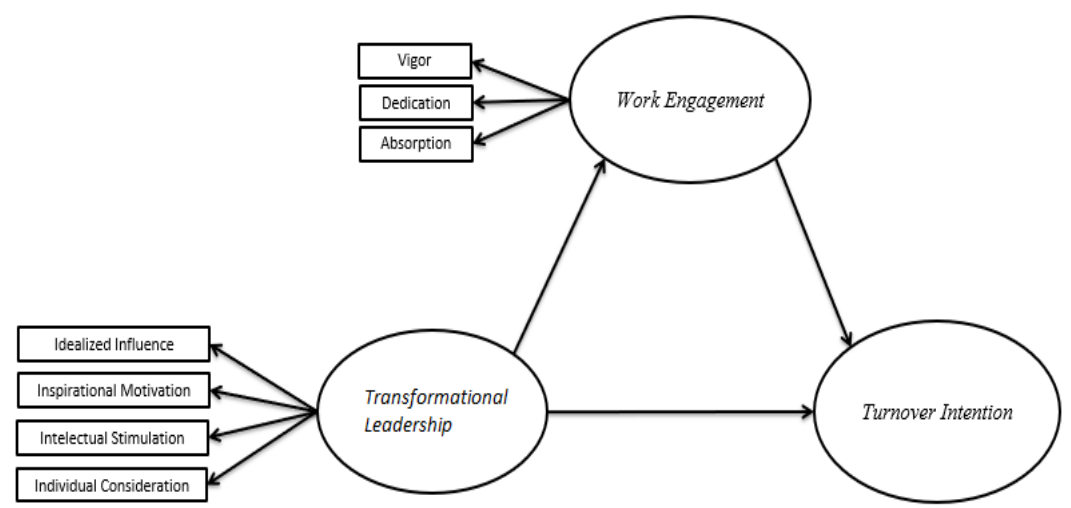

Fig 1. Theoretical Research Framework

The data analysis method used by researchers was multiple regression analysis with a mediation variable that is work engagement. According to Baron and Kenny [34]

something is called mediation if the mediation variables affect the connection among independent variables and dependent ones. By using Baron and Kenny's version of the analysis, the first step was to conduct a regression analysis among the dependent variable (turnover intention) on the independent variable (transformational leadership) as a predictor tool with the significant value was marked by $p<$ .05 . The second stage was to conduct regression analysis among mediation variables (work engagement) and the independent variable (transformational leadership) as a tool to predict the significant value, which was marked by $p<.05$. The third stage was to conduct regression analysis etween the dependent variable (turnover intention) with the mediation variable (work engagement) as a tool to predict with significant value was marked by $p<.05$. The last stage was to conduct regression analysis among the dependent variable (turnover intention) with the independent one (transformational leadership) and mediation (work engagement) as a predictor.
Based on Karatepe, Beirami, Bouzari, and Safavi [35], and consistent with extant research by Baron and Kenny [22], and Salanova and Schaufeli [22], our research showed that the indirect influences of the independent variable on the dependent one via a mediator variable were significant. Thus, the outcome also showed that the mediator variable functions as a full mediator of the influence of the independent variable on the dependent one. Gyensare, et al. [9] showed that when the independent variable had a significant influence on the mediator variable, and the mediator variable also had a significant influence on the dependent one, and the direct path from the independent variable to the dependent one was not supported, mediation was concluded to have no direct path among the independent and dependent variables. Moreover there was an outcomes that showed the direct influence of independent variables on dependent ones and had no significantly when controlling for the mediator variable, thus indicating full mediation.

H: Work engagement mediates the influence of transformational leadership on turnover intention.

In this research, researchers used transformational leadership as independent variables, work engagement as a

TABLE III. EACH DIMENSIONS FACTOR LOADING VALUE

\begin{tabular}{|c|c|}
\hline Dimensions & Loading Factor \\
\hline Idealized Influence & 0.880 \\
\hline Inspirational Motivation & 0.884 \\
\hline Intellectual Simulation & 0.942 \\
\hline Individual Consideration & 0.862 \\
\hline Vigor & 0.904 \\
\hline Dedication & 0.915 \\
\hline Absorption & 0.891 \\
\hline Turnover Intention1 & 0.876 \\
\hline Turnover Intention2 & 0.831 \\
\hline Turnover Intention3 & 0.821 \\
\hline
\end{tabular}


TABLE IV. OUtCome VALIDITY AND RELIABILITY TEST

\begin{tabular}{|c|c|c|c|}
\hline Variables - Dimensions & $\begin{array}{c}\text { umber of initial Rebuttal } \\
\text { items }\end{array}$ & $\begin{array}{c}\text { Number of remaining Statement } \\
\text { Items }\end{array}$ & Cronbach's Alpha \\
\hline TI & 3 & 3 & 0.79 \\
\hline WE - Vigor & 6 & 4 & 0.71 \\
\hline WE - Dedication & 5 & 5 & 0.77 \\
\hline WE - Absorption & 6 & 4 & 0.70 \\
\hline TL - Idealized Attributes & 4 & 4 & 0.75 \\
\hline TL - Idealized Behavior & 4 & 4 & 0.87 \\
\hline TL - Inspirational Motivation & 4 & 4 & 0.86 \\
\hline TL - Intellectual Simulation & 4 & 2 & 0.95 \\
\hline TL - Individual Consideration & 4 & 4 & 4 \\
\hline
\end{tabular}

mediation variable, and turnover intention as the dependent one. Avolio, Bass, Walumbwa, and Zhu [36] defined transformational leadership as a type of leadership that could influence workers through ideal influences, motivations, intellectual stimulation, and individual considerations. Transformational leadership consists of twenty points of affirmation, and according to Gyensare et al. (2016) [9], contains of four dimensions, namely idealized influence, inspirational motivation, intellectual stimulation, and individualized consideration. Idealized influence is the image of the transformational leader to behave in a way that generates the admiration, trust, and respect of his followers and this dimension has eight items of avowal on the questionnaire consisting of four items of statements on the sub-dimensions of idealized attributes and four items of statements on idealized sub-dimensions behaviors.

Schaufeli, et al. [19] defined work engagement as a positive, satisfying thought connected to work characterized by strength, dedication, and absorption. This variable had total of 17 items statements on the questionnaire. All sources of questionnaire statements on the transformational leadership variables use the third edition of the multifactor leadership questionnaire [19]. There are three dimensions in work engagement: vigor, dedication, and absorption. Vigor carries the idea of having a high vigor level and psychological endurance, and consists of six items of affirmation. While dedication is an engagement to his work as well as an enthusiastic feeling about his job, likewise, has five points of affirmation. Absorption is a state of concentration and enjoyment of one's job so time passes rapidly and consists of six items of affirmation. All points of the statement on the questionnaire were obtained based on the full type of the Utrecht Work Engagement Scale taken from Schaufeli, et al. [19].

There was a definition of turnover intention by Carmeli and Weisberg [15] turnover intention was a tendency that includes the possibility of someone in the near future leaving the organization. Then, according to Tett and Meyer [16] as the desire of someone to plan to leave the organization and be carried out consciously. According to Colarelli [8], turnover intention has three items of affirmations on the questionnaire.

According to Sekaran and Bougie [37], the validity test shows how well an instrument was being developed to measure a particular concept, in other words how well the researchers have measured the concept appropriately. Malhotra [32] said that high validity value indicates that measurement outcomes can be trusted, but if the validity value is low then it cannot be said to be entirely valid because in some cases a systematic error occurs. The high level of validity of an instrument also shows the extent to which the data has been collected there is no deviation from the researcher's intended objective. Associated with the validity test, the researcher used the suppressed formula in the SPSS 23 syntax code with the factor loading value below 0.5 in the automatic matrix component table, otherwise all erased. Meanwhile, the reliability test was expected to have the value of Cronbach's alpha $>0.6$ and required some items of affirmation also abolished. Of the 41 statements, there were 7 deleted statements (about 17.5\%) and there were still 34 statements maintained by the researcher. Several items of statements were eliminated for validity testing, among which were 2 items of transformational leadership and 5 points from work engagement. None of the affirmation items were deleted under the intention turnover variable. Details of deleted items can be seen in Table 2 .

Based on the facts that exist in the field, some affirmations were deleted if they were not relevant enough when adapted to the facts. One example was that in point Q2 of transformational leadership variables there was a statement "My boss thinks I have different needs, abilities and aspirations from others." In this case, as Herny [5] explained, there was a branch manager who resigned because he felt they paid less attention to the needs of leaders. According to Sekaran and Bougie [37] validity testing shows how well an instrument is being developed to measure a particular concept. In other words, whether the researchers have measured the concept appropriately. Malhotra [5] said that a high validity value indicates that the measurement outcomes can be trusted, but if the value is low then it cannot be considered entirely valid because in some cases there was a systematic error. High lows on the instrument validity level also showed the extent to which the data has been collected there was no deviation from the intended research.

A test of the reliability of the tool in this research was conducted by using internal consistency, which was conducted only once. After that, the data that already attained 
inclusion were analyzed using Cronbach's alpha. According to Malhotra [38], reliability test outcomes explain that the instruments used by researchers can be used repeatedly by giving the same or fixed outcomes. The outcomes may be utilized if the values of Cronbach's alpha are greater than 0 . Table 3 displays that the largest Cronbach's alpha value was derived from the transformational leadership variable on the individual consideration dimension with the highest Cronbach's alpha value coming in at 0.95 . A Cronbach's alpha value of 0.95 was obtained after the deletion of two questions on the questionnaire.

Related to testing the validity of each dimension, Table 4 shows that all dimensions tested in this research (i.e., idealized influence, inspirational motivation, intellectual simulation, individual consideration, vigor, dedication, absorption, turnover intention 1 , intention 2 turnover, turnover intention3) passed the validity test provisions because each had a factor loading value $>0.5$ [39].

\section{OUTCOME AND DISCUSSION}

The object of this research was permanent workers who work in all the branches of LPIA. By 2017 there were 45 active LPIA branches with a total of 164 permanent workers. The number of samples required in this research was at least 63 respondents. By using Slovin's formula, the limit of error tolerance equal to $10 \%$ of the total of the entire population that was 164 . Hence the calculation of a minimum limit from the respondent was as much as 62.12 responders (after rounding, 62 respondents).

When looking at the data in Table 4, the overall mean dimension value of the work engagement variable was moderate. It showed that LPIA workers had energy, and that their mental endurance was not necessarily low in their jobs. The enthusiasm of LPIA workers was not low and added from enjoyed what they did at their jobs and still had the will to take the time and energy to continue working.

After doing that, researchers wanted to measure the value of leadership in the LPIA. After undergoing data processing, the mean values for transformational leadership in LPIA were already high (above 3.77). This outcome illustrated that leaders in the LPIA had already applied transformational leadership very well. They have behaved in ways to generate the admiration, trust, and respect of their followers, to give meaning and challenge to the work of followers, to encourage the groups to be creative and innovative by stimulating assumptions, and trying to see problems through new and different perspectives, as well as to able to develop followers as future leaders.

Furthermore, handling hypothesis testing by using linear regression analysis with an unstandardized coefficient commonly used for regression model functions, the model was to predict the future picture with the data of the past, with mediating variables commonly used by Baron and Kenny [34].

Rendering to Baron and Kenny [34] there were three stages of investigation. If we look at Table 8 the first step that needs to be investigated is to perform a regression analysis of the connection among transformational leadership and turnover intention which displays a non-significant connection with $\beta=0.248$ and a regression significance level of 0.117 . It could be interpreted that the high turnover intention of LPIA workers was not influenced by transformational leadership. The second stage of investigators looking at the connection among transformational leadership to work engagement, outcomeed in outcomes that showed a $(+)$ and significant connection with $\beta=0.466$ significance level of 0.000 regression. In the third stage of investigation the connection among work

TABLE V. MEAN VARIABLE WORK ENGagement

\begin{tabular}{|c|c|c|c|c|}
\hline Variable-Dimensions & N & Mean & Standard Deviation \\
\hline WE & 77 & 3.5 & 0.510 \\
\hline Vigor & 78 & 3.4 & 0.530 \\
\hline Dedication & 79 & 3.7 & 0.540 \\
\hline Absorption & 78 & 3.5 & Medium & 0.630 \\
\hline
\end{tabular}

TABLE VI. Mean Variable Transformational Leadership

\begin{tabular}{|c|c|c|c|c|}
\hline Variable-Dimensions & $\mathrm{N}$ & Mean & Standard Deviation & Note \\
\hline TL & 73 & 3,8 & 0,560 & High \\
\hline Idealized Influence & 77 & 3,7 & 0,620 & High \\
\hline Inspirational Motivation & 79 & 3,8 & 0,71 & High \\
\hline Intellectual Simulation & 79 & 3,72 & 0,54 & High \\
\hline Individual Consideration & 75 & 3,77 & & \\
\hline
\end{tabular}

the data processing the concentration level of their work was not low either. Based on the mean values, that were not low, it may be concluded that LPIA workers actually still engagement with turnover intention has a (-) connection and significant connection with $\beta=-0.568$ and a regression significance level of 0.001 . 
TABLE VII. MEAN VARIABLE TURNOVER INTENTION

\begin{tabular}{|c|c|c|c|c|}
\hline Variable-Dimensions & $\mathrm{N}$ & Mean & Standard Deviation & Note \\
\hline TI & 79 & 3.0 & 0.750 & Medium \\
\hline
\end{tabular}

This finding could be construed as the high level of worker's work engagement was influenced by transformational leadership and the high turnover intention of LPIA workers was influenced by work engagement, too, so that it could be construed that work engagement represented as a full mediator among turnover intention and transformational leadership. Mediator variables are said to be full if after its inclusion, the independent variable's influence on dependent variable was insignificant after the mediator engagement as the mediator variable's functions became a full mediator of the influence of transformational leadership as a independent variable on turnover intention as dependent variable. Gyensare et. al et al. [9] also showed when an transformational leadership as an independent variable had a significant influence on a work engagement as a mediator, and work engagement as a mediator also had a significant influence on turnover intention as a dependent variable, and a direct path from transformational leadership as a

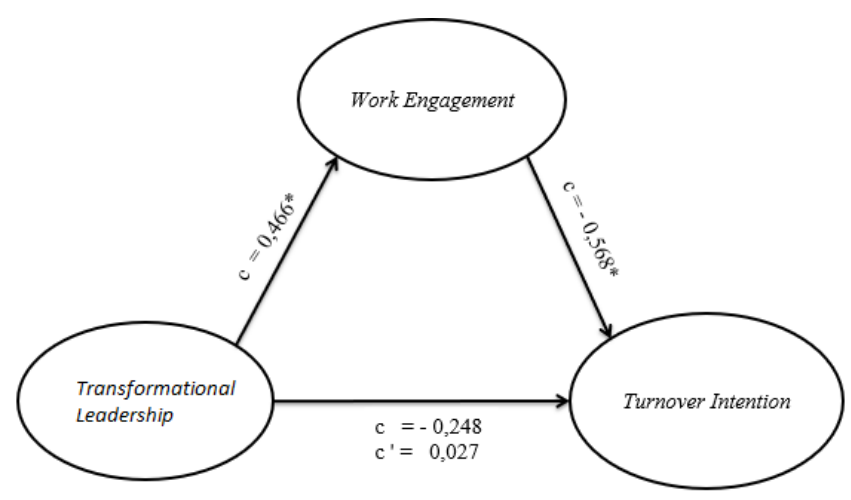

Fig 2. Hypothesis Test Outcomes

variable was involved in the regression model equation. Full mediation could also be interpreted to indicate that transformational leadership was not able to significantly influence turnover intention without going through work engagement. Based on Baron and Kenny's [34] criteria, one might conclude that the mediational hypothesis was supported. In this case, there was full mediation involved. The influence of transformational leadership on turnover intention for LPIA workers was fully mediated by the work engagement of LPIA workers.

Based on Karatepe, Beirami, Bouzari, and Safavi [35] and consistent with the extant research by Baron and Kenny [28] and Salanova and Schaufeli [28], the outcomes also showed that indirect influences of transformational leadership as a independent variable on turnover intention as a dependent variable via work engagement as a mediator variable were significant, so the outcomes also showed that work independent variable to turnover intention dependent variable the hypothesis was not supported. Thus, it was concluded that mediation of work engagement with do not exist with direct paths among transformational leadership on turnover intention. Moreover, the outcomes shown that the direct influence of transformational leadership as an independent variable on turnover intention as a dependent variable has no significantly when controlling for work engagement as a mediator variable, thus indicating full mediation. It could be concluded that the hypothesis in this research was proven, that work engagement mediate the influence among transformational leadership and turnover intention.

Based on all data were already processed, the researcher concluded that work engagement mediates among transformational leadership and turnover intention. The mean value of transformational leadership of 3.77 was high. The researcher analyzed that although there were still problems

TABLE VIII. Stages of investigation transformational leadership, work engagement, and turnover intention

\begin{tabular}{|c|c|c|c|}
\hline Regression test & $\begin{array}{c}\text { Unstandardized } \\
\text { coefficient (B) }\end{array}$ & Sig / NS \\
\hline Transformational Leadership_-Turnover Intention & -0.248 & 0.117 & NS \\
\hline $\begin{array}{c}\text { Transformational Leadership_Work Engagement- } \\
\text { Turnover Intention }\end{array}$ & 0.027 & 0.877 & $\mathrm{NS}$ \\
\hline Transformational Leadership_-Work Engagement & 0.466 & 0.000 & $\mathrm{~S}$ \\
\hline Work Engagement-Turnover Intention & -0.568 & 0.001 & \\
\hline
\end{tabular}


with workers resigning due to leadership styles, that fact did not reflect good transformational leadership. Indeed, overall respondents have assumed that the leadership in LPIA was headed by an excellent transformational leader — as described above for the case of the branch manager who resigned due to problems with the leadership style in the LPIA (in the Bintaro branch) because he felt unnoticed despite his needs, and the branch manager form Klender who resigned when his leader punished all branch managers for not reaching their targets. Nevertheless, the rest still worked for LPIA.

Other facts that support the analysis conducted by researchers related to the good leadership in LPIA showed that leaders required all workers in every branch to read the vision and mission LPIA out loud while attending the morning briefing. Doing so provided motivation to every worker of LPIA and served as proof that the leader of LPIA and almost all branch managers wanted to struggle and sacrifice on Sunday to come to the office to prepare their reports, monitoring circumstances, monitoring branch security, and planning for monthly sales target fulfillment [5]. It indirectly showed the attitude of leaders who had already reflected their actions that provided motivation and inspiration to subordinates to work better. These activities have to be maintained at LPIA. By continually motivating them, giving them good examples, they will engage in their work. If workers engage, it can reduce their desire to resign from the company. Based on the explanation from Mr. Anton as marketing director of LPIA [40], the leader of LPIA directs all workers to seek target their market from anywhere and not be limited to one thing only. Olga Herny [5] explained that he was encouraged to think creatively and innovatively to solve the problem of target fulfillment with the unlimited market, for which a majority exists in the Margonda area (e.g., students) but targeting the niche market in collaboration with local government to conduct English language training. It was already reflected in the leadership in LPIA that has been applied very well, encouraging workers to be creative and innovative. That activity also had to be maintained at the LPIA. By continually stimulating them to think creatively and innovatively about what they have to do in their work, the workers will engage in their work. If workers engage, it can reduce their desire to resign from the company. And if LPIA can retain its workers, the LPIA can better compete with its competitors. The stability of the connection among humans in the opinion of Nahapiet and Ghoshal [11] can create better outcome by the parties in the connection. According to Leana and Van Buren [11], by prioritizing the stability among individuals and having the flexibility in how individuals are placed in the connection, a unit can improve its outcome.

The mean value at turnover intention was not low at 3.02 and thus it could be analyzed by researchers that at least some workers held a possibility to resign from LPIA. When looking at the high turnover rate, personnel was integrated with the findings that branch personnel lacked initiative in their jobs and needed a leader who would be able to guide them, nurture them, and be a good example. The researchers might, therefore, conclude that LPIA management was required to prepare cadres of leaders who have a good transformational leadership style to make LPIA branch workers remain committed to their work, willing to set aside their time and effort to continue working for LPIA [12]. This notion was also supported by the outcome of this research that the connection among transformational leadership and work engagement, producing a $(+)$ and significant connection with $\beta=0.003$ level of regression significance $0,0.466$. It is also supported by previous studies undertaken by Hoper, Muser, and Janneck [23], Ghadi, Fernando, and Caputi [24], Hayati, Charkhabi and Naami [10], Wang, C. Li and X Li [25] suggests that transformational leadership has a significant and $(+)$ connection to work engagement.

Moreover, among turnover intention with work engagement had a (-) connection and significant connection with $\beta=0.001$ and level of regression significance -0.568 and supported by previous research that is research conducted by Memon, Salleh and Baharom [30], L. Lu, ACC Lu Gursoy, Neale [25], and Karatepe [41] that work engagement outcomes had (-) connection and significant outcomes on turnover intention. Researchers analyzed more deeply what the largest total influence obtained from work engagement that mediates the connection among transformational leadership and turnover intention would be that tied workers more to their jobs and made them willing to give up time and energy work at LPIA, through the role of leaders in each branch with style transformational leadership - especially at the staff level, where it may certainly reduce overall worker turnover.

\section{CONCLUSION}

One might conclude from this research that work engagement became a full mediator of transformational leadership toward turnover intention. Workers guided by a leader utilizing transformational leadership could foster a sense of being engaged in the work they do. The emergence of the work engagement factor could reduce LPIA branch worker turnover intention. One might also conclude that work engagement became full mediator with respect to turnover intention. The emergence of the work engagement factor could reduce LPIA branch worker turnover intention. Based on Karatepe, Beirami, Bouzari, and Safavi [35] and consistent with extant research by Baron and Kenny [28] and Salanova and Schaufeli [28] it also showed that the indirect influences of the independent variable (transformational leadership) on the dependent one (turnover intention) via a mediator one (work engagement) were significant, so the outcome also showed that mediator variable (work engagement) functions became a full mediator of the influence of the independent variable (transformational leadership) on dependent one (turnover intention). Based on Gyensare, et al. [9] it also showed that when the independent variable (transformational leadership) had a significant influence on a mediator one (work engagement), and the mediator one (work engagement) also had a significant influence on the dependent one (turnover intention), and a direct path from the independent one (transformational leadership) to the dependent one (turnover intention) was not supported, one might conclude that mediation of work engagement had no direct paths among transformational leadership on turnover intention. It might be concluded, too, that the hypothesis in this research was proven, that work engagement mediates the influence among transformational leadership and turnover intention.

Like previous researchers have explained, maintaining and always improving the quality of leaders in LPIA has become a very important practice in order to make them engage, thus reducing their desire to resign from the company. By continually motivating them, giving them good examples, stimulating them to think creatively and 
innovatively about what they have to do in their work, they will engage in their work. If workers engage, doing so might reduce their desire to resign from the company. And if LPIA can retain its workers, it can compete better. The stability of the connection among humans in the opinion of Nahapiet and Ghoshal [11] can create better outcome by each of the parties in a connection. According to Leana and Van Buren [11], by prioritizing stability among individuals, coupled with having the flexibility of how individuals are placed in the connection, a unit may improve its outcome.

\section{MANAGERIAL IMPLICATIONS}

The outcomes of this research showed that LPIA branch workers considered leadership received to be able to make them more engaged. Paying some attention to the needs of their workers, opportunities to think creatively and innovatively, giving good examples of leaders in the workplace can create $(+)$ influences on workers at the LPIA branch office. The more workers feel engaged in working for LPIA, the less likely they will be to resign and look for new jobs. LPIA needs to pay more attention to the type of transformational leadership that needs to be applied at the LPIA branch office so that LPIA workers feel it as an opportunity to grow, learn, and achieve a objective, arousing emotions that make work more enjoyable (Cavanaugh et al.) [35].

Some suggestions that researchers can submit for further research related to transformational leadership and turnover intention are:

1. In the next research it is suggested to use a larger sample size in order to garner much better and more accurate outcomes.

2. The researchers suggest that further studies may include other types of leadership in addition to transformational leadership, e.g.., transactional leadership.

Suggestions that researchers can submit to LPIA related to transformational leadership and turnover intention are:

1. LPIA management is expected to change the criteria and tighten the process of recruitment of leaders in each branch that has the ability to understand the needs of subordinates, providing opportunities for subordinates to be creative and innovative in making strategy fulfillment a monthly target.

2. LPIA management is expected to conduct coaching and counseling to the current branch leaders who are still serving periodically so that they can become leaders who can understand the needs of subordinates, giving an opportunity them to be creative and innovative in making strategy fulfillment a monthly target, both being role models for subordinates, and those who are able to provide them motivation.

3. Leaders in the LPIA are expected to pay more attention to the needs of staff, especially those who have been working for less than two years, so that workers have more involvement in work such as joining together when they are looking for prospective students and sharing sessions periodically to hear their complaints.

4. Leaders in the LPIA are expected to maintain the habits of all workers, reading the vision and mission statements in the morning briefings in order to encourage and be a good inspiration in the workplace and hence form the habit of spending vacation time to come to the office to supervise the workers who are working, generate reports, and oversee the creation of a monthly target plan so they feel cared for.

5. Leaders in LPIA are expected to permit branches to freely set target markets in every region where their branches are located so as to train them to think creatively and innovatively

\section{REFERENCES}

[1] SWA (2015, December 30). Kemampuan-bahasa-inggris-orangindonesia-di-level-32. Studi EF: Kemampuan Bahasa Inggris Orang Indonesia di Level, 32(July 1), 2017. Retrieved from https://swa.co.id/swa/trends/business-research/studi-ef-

[2] Xerri, D. (2016). Teaching and learning English in a multicultural classroom: Strategies and opportunities. Journal for Multicultural Education, 10(1), 19-32. doi: 10.1108/JME-04-2015-0012.

[3] Anton (2017, March). Personal interview

[4] Kementerian Pendidikan Dan Kebudayaan (2015). Sekretariat jenderal pusat data dan statistik pendidikan dan kebudayaan. In Statistik pendidikan informal. July 15, 2017.

[5] Herny, O. (2017, May). Personal interview

[6] Kompas (2010, November 3). Manusia: Menjadi aset atau biaya? Retrieved from http://ifestyle.kompas.com/read/2010/11/03/07295023/manusia. menjadi.aset.atau.biaya.

[7] SWA (2012, September 12). Kiat mempertahankan talent terbaik di perusahaan. Retrieved from https://swa.co.id/swa/trends/management/kiat-mempertahankantalent-terbaik-di-perusahaan.

[8] Saks, A. M. (2006). Antecedents and consequences of employee engagement. Journal of Managerial Psychology, 21(7), 600-619. doi: $10.1108 / 02683940610690169$

[9] Gyensare, M. A., Anku-Tsede, O. A., Sanda, M. A., \& Okpoti, C. A. (2016). Transformational leadership and employee turnover intention. World Journal of Entrepreneurship, Management and Sustainable Development, 12(3), 243-266. doi: 10.1108/WJEMSD-02-2016-0008.

[10] Hayati, D., Charkhabi, M., \& Naami, A. (2014). The relationship between transformational leadership and work engagement in governmental hospitals nurses: A survey study. A Springer Open. [Journal], 3, 25-32. doi: 10.1186/2193-1801-3-25

[11] Harris, C. M., McMahan, G. C., \& Wright, P. M. (2012). Talent and time together. Personnel Review, 41(4), 408-427. doi: 10.1108/00483481211229357.

[12] Seda (April 2017). Personal interview.

[13] Budi (2017, April). Personal interview.

[14] Kurniawan (2017, April). Personal interview

[15] Carmeli, A., \& Weisberg, J. (2006). Exploring turnover intentions among three professional groups of employees. Human Resource Development International, 9(2), 191-206. doi: $10.1080 / 13678860600616305$.

[16] Tett, R. P., \& Meyer, J. P. (1993). Job satisfaction, organizational commitment, turnover intention, and turnover: Path Analyses based on meta-analytic findings. Personnel Psychology, 46(2), 259-293. doi: 10.1111/j.1744-6570.1993.tb00874.x

[17] Slåtten, T., Svensson, G., \& Sværi, S. (2011). Service quality and turnover intentions as perceived by employees. Personnel Review, 40(2), 205-221. doi: 10.1108/00483481111106084.

[18] Wong, Y. T., Wong, Y. W., \& Wong, C. S. (2015). An integrative model of turnover intention. Journal of Chinese Human Resources Management, 6(1), 71-90. doi: 10.1108/JCHRM-062014-0015.

[19] Schaufeli, W. B., \& Bakker, A. B. (2004). Job demands, job resources, and their relationship with burnout and engagement: A multi-sample study. Journal of Organizational Behavior, 25(3), 293-315. doi: $10.1002 /$ job.248 
[20] Koyuncu, M., Burke, R. J., \& Fiksenbaum, L. (2006). Work engagement among women managers and professionals in a Turkish bank. Equal Opportunities International, 25(4), 299-310. doi: $10.1108 / 02610150610706276$

[21] Wollard, K. K., \& Shuck, B. (2011). Antecedents to employee engagement. Advances in Developing Human Resources, 13(4), 429-446. doi: $10.1177 / 1523422311431220$.

[22] Shantz, A., Alfes, K., \& Latham, G. P. (2016). The buffering effect of perceived organizational support on the relationship between work engagement and behavioral outcomes. Human Resource Management, 55(1), 25-38. doi: 10.1002/hrm.21653.

[23] Vincent-Höper, S. V., Muser, C., \& Janneck, M. (2012). Transformational leadership, work engagement, and occupational success. Career Development International, 17(7), 663-682. doi: 10.1108/13620431211283805.

[24] Yasin Ghadi, M. Y., Fernando, M., \& Caputi, P. (2013). Transformational leadership and work engagement. Leadership and Organization Development Journal, 34(6), 532-550. doi: 10.1108/LODJ-10-2011-0110.

[25] Wang, Z., Li, C., \& Li, X. (2017). Resilience, leadership and work engagement: The mediating role of positive affect. Social Indicators Research, 132(2), 699-708. doi: 10.1007/s11205-0161306-5

[26] Wells, E. J., \& Peachey, J. W. (2011). Turnover intentions: Do leadership behaviors and satisfaction with the leader matter? Team Performance Management. Anais: an International Journal, $17(1 / 2), 23-40$

[27] Green, A. E., Miller, E. A., \& Aarons, G. A. (2013). Transformational leadership moderates the relationship between emotional exhaustion and turnover intention among community mental health providers. Community Mental Health Journal, 49(4), 373-379. doi: 10.1007/s10597-011-9463-0. PubMed: 22052429.

[28] Agarwal, U. A., Datta, S., Blake-Beard, S. B., \& Bhargava, S. (2012). Linking LMX, innovative work behaviour and turnover intentions. Career Development International, 17(3), 208-230. doi: $10.1108 / 13620431211241063$.

[29] Lu, L., Lu, A. C. C., Gursoy, D., \& Neale, N. R. (2016). Work engagement, job satisfaction, and turnover intentions. International Journal of Contemporary Hospitality Management, 28(4), 737-761. doi: 10.1108/IJCHM-07-2014-0360

[30] Memon, M. A., Salleh, R., \& Baharom, M. N. R. (2016). The Link between training satisfaction, work engagement and turnover intention. European Journal of Training and Development, 40(6), 407-429. doi: 10.1108/EJTD-10-2015$\underline{0077 .}$

[31] Metin Camgoz, S., Tayfur Ekmekci, O., Bayhan Karapinar, P., \& Kumbul Guler, B. (2016). Job insecurity and turnover intentions: Gender differences and the mediating role of work engagement. Sex Roles, 75(11-12), 583-598. doi: 10.1007/s11199-016-05950 .

[32] Malhotra, N. K. (2010). Marketing research: An applied approach. (4th edition). New York: Pearson education.

[33] Pawirosumarto, S., Sarjana, P. K., \& Muchtar, M. (2017). Factors affecting employee performance of PT. Kiyokuni Indonesia. International Journal of Law and Management, 59(4), 322-340.

[34] Baron, R. M., \& Kenny, D. A. (1986). The moderator-mediator variable distinction in social psychological research: Conceptual, strategic, and statistical considerations. Journal of Personality and Social Psychology, 51(6), 1173-1182. doi: 10.1037/00223514.51.6.1173. PubMed: $\underline{3806354}$.

[35] Karatepe, O. M., Beirami, E., Bouzari, M., \& Safavi, H. P. (2014). Does work engagement mediate the effects of challenge stressors on job outcomes? Evidence from the hotel industry. International Journal of Hospitality Management, 36, 14-22. doi: 10.1016/j.ijhm.2013.08.003.

[36] Avolio, B. J., \& Bass, B. M. (1995). Multifactor leadership questionnaire (3rd ed). Redwood City, CA: Mind Garden, Inc.

[37] Sekaran, U., \& Bougie, R. (2013). Research methods for business-A skill building approach (6th ed). West Sussex, UK: John Wiley \& Sons.

[38] Malhotra, N. K., Birks, D. F., \& Wills, B. (2012). Introduction: A Contextual and Resource-Integrative View of Value Creation.
Review of Marketing Research, xiii-xixv. doi: 10.1108/S15486435(2012)0000009004:

[39] Hair, J. F., Black, W. C., Babin, B. J., \& Anderson, R. E. (2010). Multivariate data analysis (7th ed). New York: Pearson Prentice Hall http://new http://indonesia.org/beranda/images/upload/dok/edustat/Statistik - Pendidikan-Informal-2015.pdf.

[40] LPIA (2017). Job description Lembaga Pendidikan Indonesia Amerika. Indonesia: Graha LPIA.

[41] Karatepe, O. M. (2013). Perceptions of organizational politics and hotel employee outcomes. International Journal of Contemporary Hospitality Management, 25(1), 82-104. doi: 10.1108/09596111311290237.

[42] Cooper, D. R., \& Schindler, P. S. (2008). Business research methods (10th ed). New York: McGraw-Hill. 